\title{
Arbejdsmarkedet og krisen - en indledning
}

Rasmussen, Stine; Larsen, Trine Pernille; Sørensen, Ole H.

Published in:

Tidsskrift for Arbejdsliv

Publication date:

2015

Document version

Også kaldet Forlagets PDF

Citation for published version (APA):

Rasmussen, S., Larsen, T. P., \& Sørensen, O. H. (2015). Arbejdsmarkedet og krisen - en indledning. Tidsskrift for Arbejdsliv, 17(3), 5-9. http://www.nyt-om-arbejdsliv.dk/images/pdf/2015/nr3/tfa3_2015_005_009.pdf 


\section{Arbejdsmarkedet og krisen - en indledning}

Stine Rasmussen, Trine P. Larsen \& Ole H. Sørensen

$\mathrm{D}$ ette nummer af Tidsskrift for Arbejdsliv bærer temaet "Arbejdsmarkedet og krisen", som henviser til perioden fra og med efteråret 2008, hvor Danmark blev ramt af den internationale, finansielle og økonomiske krise. Med termen finanskrise forstås en krise på de finansielle markeder, mens økonomisk krise henviser til, når den finansielle krise får økonomiske implikationer som fx et fald i efterspørgslen eller væksten eller en stigende ledighed (Madsen 2010, 35).

Krisen havde som bekendt sin oprindelse i USA og kobles til uroen omkring de såkaldte 'subprime-lån', hvor der var blevet givet for mange lån til låntagere uden tilstrækkeligt indkomstgrundlag til at tilbagebetale dem (Andersen 2013, 48; Berg \& Bech 2009, 95-96). Krisens begyndelse tidsfæstes i den brede offentlighed til investeringsbanken Lehman Brothers' konkurs d. 15. september 2008, selvom finansøkonomer peger på, at den tog sin begyndelse allerede i sommeren 2007 (Berg 2010, 5). Efter Lehman Brothers' konkurs fulgte hvad Jørgen Goul Andersen betegner som en 'finansiel tsunami', hvor regeringerne i en række lande iværksatte forskellige krisepakker og bankredninger for at undgå nedsmeltning i den internationale økonomi (Andersen 2013, 45). Selvom det lykkedes for flere lande at få stimuleret økonomien, faldt verdenshandlen alligevel drastisk i 2009, og derfor blev både USA og
Europa kastet ud i en alvorlig økonomisk krise (Andersen 2013, 46).

Der er generel enighed om, at krisen ramte hårdt i Danmark. Det ses eksempelvis ved, at det danske bruttonationalprodukt faldt med sammenlagt 6,4\% i 2008 og 2009, hvilket er et markant større fald end under tidligere kriser (Andersen 2013, 46). Også privatforbruget faldt med 3,2\% i årene fra 2007 til 2011, hvilket er et fald, som kun var set større i få andre lande, bl.a. de sydeuropæiske (Andersen 2013, 50). Og på arbejdsmarkedet var der en betydelig stigning i ledigheden fra og med anden halvdel af 2008 og fortsat ind i 2009 . I 2009 nåede den registrerede ledighed op på knap 100.000 fuldtidsledige, hvilket var en fordobling i forhold til den historisk lave ledighed, der var i 2008 før krisen ramte (Danmarks Statistik 2011, 98).

Den forklaring, der ofte gives på, at krisen ramte Danmark så hårdt, er, at der i den forudgående periode var blevet ført en politik, som havde ledt til en overophedning af økonomien og som dermed forstærkede den økonomiske nedtur, der fulgte af den internationale finansielle krise (Sørensen 2010). Et element af dette er, at der over tid var blevet opbygget en bolig- og kreditboble bl.a. som følge af indførelsen af afdragsfrie lån, som var ved at briste, da den internationale krise gjorde sit indtog (Andersen 2013, 46;48). 
I Danmark blev der fra politisk hold i tiden efter krisens indtog iværksat en række forskellige reformer og økonomiske besparelser i forsøget på at genoprette dansk økonomi og føre Danmark ud af krisen. Eksempelvis blev der i finanssektoren indført en række bankpakker, der på forskellige måder forsøgte at styrke bankerne og genoprette tilliden til pengeinstitutterne. Et andet eksempel er Genopretningspakken fra 2010, der bestod af forskellige initiativer til at nedbringe det offentlige underskud. Et element heri var vedtagelsen af en halvering af dagpengeperioden fra fire til to år og en fordobling af genoptjeningskravet fra seks til 12 måneder. Konsekvenserne af særligt dette initiativ har været og er fortsat meget omdiskuteret, fordi et forholdsmæssigt stort antal ledige faktisk faldt ud af dagpengesystemet i tiden derefter, og mange mistede derfor deres forsørgelsesgrundlag. Det drejede sig således om markant flere ledige, end hvad forventningen var, da reformen blev vedtaget tilbage $\mathrm{i}$ 2010 af den dengang siddende VK-regering med støtte fra en række andre partier (Kirk 2014). SR-regeringen, der i 2011 efterfulgte VK-regeringen, forsøgte sig med forskellige midlertidige lappeløsninger, der kunne sikre, at færre mistede deres dagpenge. Status i dag er dog, ifølge tal fra a-kassernes brancheorganisation AK Samvirke, at cirka 54.000 mennesker har mistet deres dagpengeret siden 2013 (Klos 2015).

Også på andre arenaer blev der reageret på krisesituationen. Eksempelvis har arbejdsmarkedets parter både under de centrale overenskomstforhandlinger i den offentlige og private sektor iværksat forskellige initiativer, ligesom parterne lokalt på danske virksomheder har udviklet en række tiltag med henblik på at imødegå de udfordringer, der er fulgt i kølvandet på den økonomiske krise. Løntilbageholdenhed har således præget de senere års offentlige og private overenskomstrunder og førte i henholdsvis 2010 og 2012 til historisk lave lønstigninger i den private sektor (Mailand \& Hansen 2015; Andersen \& Ibsen 2014). Andre konkrete tiltag siden krisens indtog har bl.a. indbefattet nye muligheder og rettigheder $i$ forhold til efteruddannelse - både i den offentlige og private sektor, hvor $\mathrm{fx}$ muligheden for efteruddannelseskurser i opsigelsesperioder og under arbejdsfordeling er blevet tilføjet en række sektoroverenskomster i de senere år (Andersen \& Ibsen 2014; Mailand 2013, Mailand \& Hansen 2015). Derudover har der været en øget brug af muligheden for arbejdsfordeling særlig i årene lige efter krisens indtog. Ordningen, der giver tillidsrepræsentanter og ledere mulighed for at indgå lokalaftaler om arbejdsfordeling, er dog ikke ny, men blev indskrevet første gang i fx industriens overenskomster i 1981 (Andersen 2009). I foråret 2009 toppede brugen af arbejdsfordeling med 20.176 lønmodtagere på den type ordninger mod blot 816 året før (Andersen 2009). Andre eksempler på krisetiltag, som ledere og tillidsrepræsentanter på såvel offentlige som private arbejdspladser har udviklet i fællesskab, har været lokalaftaler om lønstop, løntilbagegang samt håndtering af afskedigelser mv. (Navrbjerg \& Larsen 2015).

Blandt befolkningen synes krisesituationen også at have forplantet sig i bevidstheden og har på nogle områder skabt en vis utryghed. Ifølge Trygfondens Tryghedsmåling i 2011 har der eksempelvis været en stigning i andelen af danskere, der var bange for at miste deres arbejde, hvis man sammenligner med før (2004, 2005 og 2007) og under krisen (2009 og 2011). Det samme gælder frygten for at mangle penge, hvis der kommer en uventet udgift (Andersen 2013, 53). Undersøgelsen viste også, at særligt studerende (mere end $50 \%$ ) frygtede ikke at kunne finde arbejde efter endt uddannelse (Andersen 2013, 53). 
Der er således ingen tvivl om, at perioden fra og med 2008 på mange måder har været en turbulent tid præget af ustabilitet, utryghed og forandring på det danske arbejdsmarked. Temaredaktionen valgte derfor at søge efter bidrag, der kunne formidle aktuel forskning om det danske arbejdsmarked og det danske arbejdsliv i en krisetid. Temaredaktionen havde en særlig interesse i at få belyst de udfordringer, som krisen stiller det danske arbejdsmarked overfor; de konsekvenser, som krisen har for arbejdslivet og arbejdsmarkedet; samt de forandringer, som krisen kan tænkes at medføre på forskellige niveauer af arbejdslivet og på arbejdsmarkedet. Temanummeret rummer derfor fire artikler, der på forskellig vis behandler og giver indsigt i disse problemstillinger. Udover de fire artikler består nummeret også af en kronik og fire anmeldelser.

Den første artikel "Fællesskab før forskelle - lønmodtagernes erfaringer og holdninger før og efter krisen" af Emmett Caraker, Laust Høgedahl, Henning Jørgensen og Rasmus Møberg sætter fokus på forandringer i lønmodtagernes værdier og interesser før og efter krisen. Med afsæt i en større longitudinal kvantitativ undersøgelse med danske lønmodtagere belyser forfatterne forandringer i danske lønmodtageres værdier og interesser over tid. Deres teoretiske afsæt er magtressourceteori og kritik af individualiseringsteorier, og gennem deres empiriske analyse sætter forfatterne således spørgsmålstegn ved solidaritetens forsvinden, hvilket er et argument, der ofte fremhæves i individualiseringsteorierne. Forfatterne konkluderer, at der stadig er mange delinger blandt danske lønmodtagere, men at der er nye tendenser at spore på arbejdsmarkedet mod kollektive løsninger og mindre individualisering, hvor især krisen synes at have øget lønmodtagernes opbakning til fagforeningerne og de kollektive instanser.

Temanummerets anden artikel "Samar- bejde og forhandling i krisetider" af Steen Navrbjerg og Trine P. Larsen retter sig mod arbejdspladsniveauet og beskæftiger sig med forholdet mellem ledelse og tillidsrepræsentant, når virksomheder står overfor krise. Forfatterne søger at belyse, hvordan kriser i organisationen påvirker forholdet mellem ledelsen og tillidsrepræsentanterne. Analyserne viser, at parterne på hårdest ramte virksomheder i højere grad har søgt at komme i dialog og har udviklet flest fælles tiltag. Analyserne viser dog også, at fronterne mellem parterne typisk skærpes, når den økonomiske situation forværres. Der er en tendens til, at ledelsesstilen ændres fra en mere partsorienteret ledelsesstil mod en mere traditionel ledelsesstil, hvor medarbejderinddragelse holdes på et minimum. Modsat har tillidsrepræsentanterne ofte en mere konfliktorienteret tilgang til samarbejdet. Tendenserne er således modsætningsfyldte, hvilket blandt andet kan skyldes, at de institutionelle rammer spiller en afgørende rolle for, hvordan kriser tackles på arbejdspladsen, fordi aftalesystemet ikke stiller krav om medarbejderinddragelse på samme måde, som samarbejdssystemet gør. Resultaterne tyder i den forbindelse på, at tillidsforholdet mellem ledelsen og tillidsrepræsentanten har større betydning, når de institutionelle rammer ikke stiller formelle krav til medarbejderinddragelse.

Den tredje artikel "Mellem arbejde og 'offday' - tvetydighedens muligheder i sociale virksomheder" af Rikke Egaa Jørgensen og Silla Marie Mørch Sievers giver et kvalitativt og mikro-orienteret blik på, hvordan arbejdet opfattes og praktiseres i såkaldte WISES, der forstås som socialøkonomiske virksomheder, der arbejder med arbejdsintegration af udsatte borgere. Forfatternes afsæt er, at gruppen af socialt udsatte blev ramt dobbelt i forbindelse med krisen, dels fordi der blev færre jobs og dels på grund af kommunale besparelser på det sociale område. De 
såkaldte WISES fremhæves som havende et særligt potentiale til at løfte denne dobbelte udfordring. I en tid, hvor arbejde betyder meget for det enkelte menneske, men hvor det på grund af krisen er en begrænset ressource, er det endvidere vigtigt at skabe nye veje ind i arbejdsfællesskaber for mennesker i udsatte positioner. På baggrund af to længerevarende feltstudier i to WISES viser forfatterne, hvilke tvetydigheder og paradokser der opstår i arbejdet i WISES, og hvordan deltagerne bevæger sig mellem forskellige positioner i og udenfor arbejdet, når de er i WISES. Forfatterne konkluderer, at arbejdsintegration kun lykkes delvist i de to studerede organisationer, men peger samtidig på, at WISES snarere bør betragtes som en anden form for arbejdsfællesskab, der kan skabe mening og legitimitet for deltagerne, selvom det ikke er et decideret lønarbejde.

Temanummerets fjerde og sidste artikel "Performance management i en krisetid" af Claus Elmholdt, Rasmus Hoffmann Birk og Kenneth Børgesen undersøger om 'performance management' eller på dansk 'præstationsledelse' er et effektivt svar på de udfordringer, som organisationer står overfor i krisetider, hvor fokus er rettet mere mod organisationers overlevelse fremfor forbedret præstation. Med afsæt i en konkret case, Touch-It, analyserer og diskuterer forfatterne en række faldgruber i forhold til præstationsledelse i en krisetid. De konkluderer, at 'performance management'-systemer er nødvendige i organisationer, særligt i krisetider, hvor der kan være ekstra behov for fa-

\section{REFERENCER}

Andersen, Jørgen Goul (2013): Den økonomiske udvikling op til 2011-valget, i Rune Stubager, Hansen, Kasper Møller \& Jørgen Goul Andersen (red.): Krisevalg. Økonomien og ste holdepunkter, men peger samtidig på, at den konkrete praksis for præstationsledelse skal integrere styring, kontrol og læring.

Temanummeret indeholder også en kronik, der kigger ud over Danmarks grænser og giver indsigt $i$, hvordan krisen ramte det portugisiske arbejdsmarked. Maria da Paz Compos Lima belyser de sparepolitikker, som er blevet gennemført i Portugal under den økonomiske krise, og diskuterer deres betydning for den portugisiske arbejdsmarkedsmodel. Maria da Paz Campos Lima viser, at de reformer, som er fulgt i kølvandet på den økonomiske krise, og særligt tiltagene, der blev iværksat i forbindelse med Troikaindgrebene, har haft mærkbare konsekvenser for den portugisiske arbejdsmarkedsmodel. Det gælder ikke kun i forhold til overenskomstdækningen og parternes muligheder for kollektive forhandlinger, men også med hensyn til forskellige sociale velfærdsgoder. Med afsæt i den portugisiske situation og en komparativ diskussion af betydningen af EU's seneste økonomiske tiltag for medlemslandenes velfærds- og arbejdsmarkedsmodeller, fremhæver forfatteren afslutningsvis behovet for et øget fokus på genopbygningen af det sociale Europa, som kan sætte en stopper for EU's neoliberale krisetiltag, der i øjeblikket skyller indover Europa.

God læselyst!

Stine Rasmussen, Trine P. Larsen og

Ole H. Sørensen

Temaredaktører
Folketingsvalget 2011, København, Jurist- og Økonomforbundets Forlag, 45-59. Andersen, Søren Kaj (2009): Tackling job-losses - varieties of European responses, paper 
præsenteret ved $4^{\text {th }}$ EU-China High Level Roundtable on Social Security, Stockholm, 15. til 16. oktober 2009.

Andersen, Søren Kaj \& Christian Lyhne Ibsen (2014): Vejen ud af krisen, forskningsnotat, 138, København, FAOS.

Berg, Jesper (2010): Finansernes fald. Den korte version, i Samfundsøkonomen, 2010, 1, 5-10.

Berg, Jesper \& Morten L. Bech (2009): Finansernes fald. Hvordan den perfekte storm vaeltede de finansielle markeder, København, Gyldendal.

Danmarks Statistik (2011): Statistisk Årbog 2010, København, Danmarks statistisk.

Kirk, Verner Sand (2014): Danmarkshistoriens alvorligste regnefejl, fundet på http://aksamvirke.dk/artikler/danmarkshistoriensalvorligste-kommafejl, 24. august 2015, AK Samvirke.

Klos, M. (2015): Opbrugt ret til dagpenge og mid- lertidig arbejdsmarkedsydelse. Status for 2013 og 2014, Notat, AK Samvirke.

Madsen, Poul Thøis (2010): Hvad gør medierne ved krisen? Om vagt- og skødehunde...., i Samfundsøkonomen, 2010, 1, 35-39.

Mailand, Mikkel (2013): Arbejdsgivernes politik og adfoerd, lønmodtagernes alliancer og organisationsformer, forskningsnotat, 135, København, FAOS.

Mailand, Mikkel \& Nana Wesley Hansen (2015): Vindstød uden stormstyrke - Overenskomstfornyelsen 2015 i den offentlige sektor, forskningsnotat, 145, København, FAOS.

Navrbjerg, Steen E. \& Trine P. Larsen (2015): Samarbejde og forhandling i krisetider, i Tidsskrift for Arbejdsliv, 17, 3, 29-47.

Sørensen, Peter Birch (2010): Nedturen i dansk økonomi. Hvor meget var selvforskyldt?, i Samfundsøkonomen, 2010, 1, 29-34. 